\title{
A Water-repellent Silanization Coating Technique for MEMS
}

\author{
Keiichi Shimaoka Member (Toyota Central R\&D Labs.,Inc., shimaoka@mosk.tytlabs.co.jp) \\ Hideki Hosokawa Non-member (Toyota Central R\&D Labs.,Inc., e0694@mosk.tytlabs.co.jp) \\ Hirohumi Funabashi Non-member (Toyota Central R\&D Labs.,Inc., h-funabashi@mosk.tytlabs.co.jp) \\ Yasuichi Mitsushima Non-member (Toyota Central R\&D Labs.,Inc., y-mitsushima@mosk.tytlabs.co.jp)
}

Keywords : surface micromachining, micro-sensor, micro-electro-mechanical systems, water-repellent silanization coating

We developed a gas-phase water-repellent silanization coating technique that prevents the microscopic structures that are used for micro-sensors and micro-electro-mechanical systems (MEMS) from sticking to the silicon substrates and other microscopic structures during operation. A water-repellent coating reduces the surface energy of the structure. The water-repellency characteristics of three types of organosilicon compounds (n decyltrichlorosilane; $\mathrm{C}_{10} \mathrm{H}_{21} \mathrm{Cl}_{3} \mathrm{Si}, 3,3,4,4,5,5,6,6,6$ nonafluorohexyltrichlorosilane; $\mathrm{C}_{6} \mathrm{H}_{4} \mathrm{Cl}_{3} \mathrm{~F}_{9} \mathrm{Si}$, (tridecafluoro - 1, 1, 2, 2 - tetrahydrooctyl) trichlorosilane; $\mathrm{C}_{8} \mathrm{H}_{4} \mathrm{Cl}_{3} \mathrm{~F}_{13} \mathrm{Si}$ ) were evaluated. We found that a water-repellent silanization coating layer of $\mathrm{C}_{8} \mathrm{H}_{4} \mathrm{Cl}_{3} \mathrm{~F}_{13} \mathrm{Si}$ had superior durability. We confirmed that the water contact angle of the $\mathrm{C}_{8} \mathrm{H}_{4} \mathrm{Cl}_{3} \mathrm{~F}_{13} \mathrm{Si}$ coating layer exceeds 90 degrees at the surfaces of the materials with the exception of nickel, in electric devices. In addition, the $\mathrm{C}_{8} \mathrm{H}_{4} \mathrm{Cl}_{3} \mathrm{~F}_{13} \mathrm{Si}$ coating layer can be patterned by ultraviolet irradiation (wavelengths 185 $\mathrm{nm}$ and $254 \mathrm{~nm}$ ).

A schematic representation of the silanization coating reaction resulting from the organosilicon compound gas and $\mathrm{H}_{2} \mathrm{O}$ gas is shown in Fig. 1. Figure 2 shows the schematic of a water droplet on the silicon surface after a silanization coating. When the water contact angle is greater than 90 degrees, sticking on wet samples can be prevented.

The durability of the coating layers was evaluated under heat, moisture and chemical processes. Evaluation results are summarized in Table 1 . When the water contact angle after the various tests was found to be greater than 90 degrees, the coating layer was considered to be durable. These results indicate that a coating layer obtained with $\mathrm{C}_{8} \mathrm{H}_{4} \mathrm{Cl}_{3} \mathrm{~F}_{13} \mathrm{Si}$ had superior durability.

We expect the $\mathrm{C}_{8} \mathrm{H}_{4} \mathrm{Cl}_{3} \mathrm{~F}_{13} \mathrm{Si}$ coating to prove useful for improving the performance of micro-sensors and MEMS.

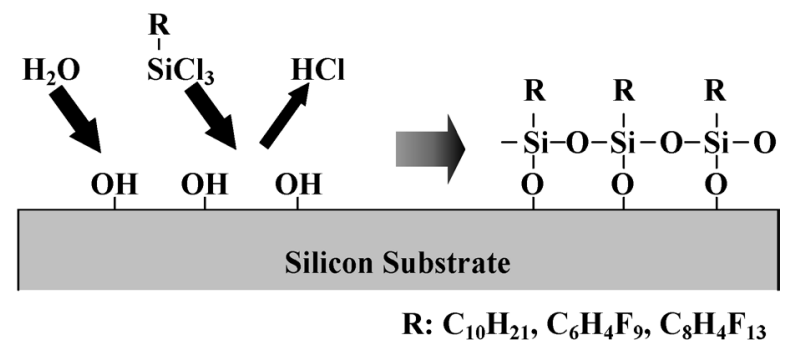

Fig. 1. Schematic of silanization reaction

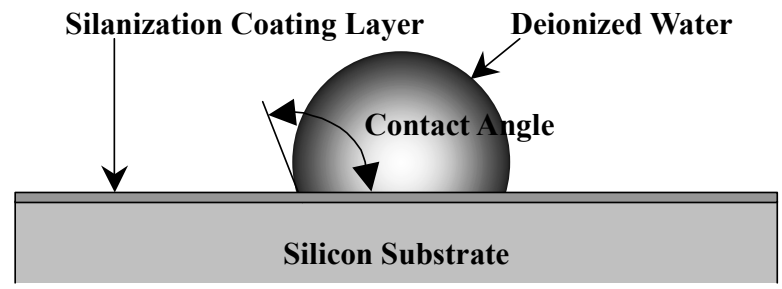

Fig. 2. Schematic of water droplet on silicon surface

Table 1. Results of durability test of silanization coating layers

\begin{tabular}{|c|c|c|c|c|c|}
\hline \multicolumn{3}{|c|}{ Test Items } & \multicolumn{3}{|c|}{ Organosilicon Compounds } \\
\hline \multicolumn{2}{|c|}{ Exposure Items } & Condition & $\mathrm{C}_{10} \mathrm{H}_{21} \mathrm{Cl}_{3} \mathrm{Si}$ & $\mathrm{C}_{6} \mathrm{H}_{4} \mathrm{Cl}_{3} \mathrm{~F}_{9} \mathrm{Si}$ & $\mathrm{C}_{8} \mathrm{H}_{4} \mathrm{Cl}_{3} \mathrm{~F}_{13} \mathrm{Si}$ \\
\hline \multicolumn{2}{|c|}{ Heat } & $100 \sim 500{ }^{\circ} \mathrm{C}, 30 \mathrm{~min}$ & $50{ }^{\circ} \mathrm{C}(90)$ & $300{ }^{\circ} \mathrm{C}(92)$ & $300{ }^{\circ} \mathrm{C}(96)$ \\
\hline \multicolumn{2}{|c|}{ Low-temperature } & $-30{ }^{\circ} \mathrm{C}, 30 \mathrm{~min}$ & D (92) & D (96) & D (99) \\
\hline \multicolumn{2}{|c|}{ Moisture } & $75{ }^{\circ} \mathrm{C}, 40 \sim 95 \% \mathrm{RH}$ & N. D. (60) & D (93) & D (98) \\
\hline \multicolumn{2}{|c|}{ Deionized Water } & R. T., 30 120 min & N. D. (89) & D (94) & D (97) \\
\hline \multirow{3}{*}{$\begin{array}{l}\text { Organic } \\
\text { Solvent }\end{array}$} & 2-Butanon & R. T., 30 min & N. D. (88) & D (94) & D (94) \\
\hline & Acetone & R. T., 30 min & D (92) & D (96) & D (96) \\
\hline & Methanol & R. T., 30 min & N. D. (88) & D (96) & D (94) \\
\hline \multirow{2}{*}{$\begin{array}{c}\text { Hydrofluoric } \\
\text { Acid }\end{array}$} & Diluted HF & R. T., 30 min & N. D. (86) & N. D. (78) & N.D. (76) \\
\hline & Buffered HF & R. T., $30 \mathrm{~min}$ & D (92) & N. D. (80) & D (96) \\
\hline
\end{tabular}

Number in parenthesis indicates water contact angle after tests. R. T. : room temperature, D : durable, N. D. : not durable 


\title{
MEMS 用撥水性シリル化コーティング技術
}

\author{
正員 島岡 敬一* 非会員 細川 秀記* \\ 非会員 船橋 博文* 非会員 光嶋 康一 *
}

\author{
A Water-repellent Silanization Coating Technique for MEMS \\ Keiichi Shimaoka*, Member, Hideki Hosokawa*, Non-member, Hirohumi Funabashi*, Non-member, \\ Yasuichi Mitsushima*, Non-member
}

A gas-phase water-repellent silanization coating technique, which prevents the microscopic structures used for micro-sensors and micro-electro-mechanical systems (MEMS) from sticking to the silicon substrates and other microscopic structures during operation, have been developed. Use of a water-repellent coating is one method that prevents sticking by reducing the surface energy of the structure. The water-repellency characteristics of three types of organosilicon compounds were evaluated. It was found that a water-repellent silanization coating layer using (tridecafluoro - 1, 1, 2, 2 -tetrahydrooctyl) trichlorosilane $\left(\mathrm{C}_{8} \mathrm{H}_{4} \mathrm{Cl}_{3} \mathrm{~F}_{13} \mathrm{Si}\right)$ had most excellent durability. It was confirmed that the water contact angle of $\mathrm{C}_{8} \mathrm{H}_{4} \mathrm{Cl}_{3} \mathrm{~F}_{13} \mathrm{Si}$ coating layer is exceeding 90 degrees at surface of standard semiconductor materials except nickel. In addition, the $\mathrm{C}_{8} \mathrm{H}_{4} \mathrm{Cl}_{3} \mathrm{~F}_{13} \mathrm{Si}$ coating layer can be patterned by ultraviolet irradiation.

キーワード : 表面マイクロマシニング, マイクロセンサ, 微小電気機械システム, 撥水性シリル化コーティング

Keywords : Surface Micromachining, Micro-sensor, Micro-electro-mechanical systems, Water-repellent Silanization Coating

\section{1. はじめに}

シリコン基板上に微小な可動構造体を形成する表面マイ クロマシニング技術を応用したマイクロセンサや MEMS の研究, 開発が盛んに行われている。この微小構造体は, その直下の犠牲層と呼ばれる薄膜材料をアンダーカットエ ッチングすることによって作製される。しかし，微小構造 体の形成に成功したとしても動作中においてシリコン基板 や別の構造体に張り付いてしまうスティッキング現象が剛 性の低い構造体の場合に生じることがある。微小構造体の スティッキング防止法の一つとして有機ケイ素化合物を用 いた撥水性シリル化コーティングがある(1) (6)。シリル化コ 一ティングは, 表面エネルギーを低下させることによりス ティッキングを防止する方法である。有機ケイ素化合物を 表面にコーティングすると長鎖のアルキル基が基板に対し て垂直方向に規則正しく並んだ膜が形成される。これを自 己組織化膜と呼ぶ。この自己組織化膜は単分子膜であるの で, コーティング処理前後の微小構造体の機械的特性を変 化させることが少なく, 低剛性の構造体へのコーティング

\footnotetext{
* (株)豊田中央研究所

T480-1192 愛知県愛知郡長久手町長湫横道 41-1

Toyota Central R\&D Labs., Inc.

41-1 Nagakute, Aichi 480-1192
}

法として有効である。シリコン基板上にシリコン構造体を 形成寸る場合、酸化膜系の犠牲層材料を使用し、フッ化水 素酸系の溶液あるいはガスにより犠牲層材料をエッチング 除去してシリコン構造体をシリコン基板よりリリース寸 る。このように処理したシリコン表面は水素によりターミ ネーションされているので, 過酸化水素酸などを用いて酸 化処理を行い, 十分な量の水酸基サイトを形成した後, 有 機ケイ素化合物の液体あるいはガスを供給して縮合反応を 起こさせシリル化コーティング層を形成している(2) (5)。有 機ケイ素化合物の液体を用いた液相処理法は, コーティン グ処理中の湿度管理や，コーティング処理後の洗浄用に多 量の溶媒を必要と寸る。また, 表面マイクロマシニングで は, シリコン基板とのギャップが数 $\mu \mathrm{m}$ という狭い間隙を 有する構造体内部をシリル化コーティングする必要があ る。これより, マイクロセンサや MEMS では, 液相処理法 よりもガスを用いた気相処理法の方が適していると考えら れる。

そこで, 我々はシリル化コーティング処理の工程数の削 減を目的として, 気相処理法で, 且つフッ化水素酸を用い た犠牲層エッチング後のシリコン表面の酸化処理を必要と しないシリル化コーティング技術の開発を進めている(7) (9)。 この方法は, 水蒸気と有機ケイ素化合物のガスを交互に供 
給し，水を基板表面に吸着させながらシリル化コーティン グ処理を行うものである。

本稿では，まず，アルキル基を分子内に有する $\mathrm{n}$ デシル トリクロロシラン $\left(\mathrm{C}_{10} \mathrm{H}_{21} \mathrm{Cl}_{3} \mathrm{Si}\right)$, フルオロアルキル基を分 子内に有する $3,3,4,4,5,5,6,6,6$ ノナフルオロヘキシル トリクロロシラン $\left(\mathrm{C}_{6} \mathrm{H}_{4} \mathrm{Cl}_{3} \mathrm{~F}_{9} \mathrm{Si}\right)$ とトリデカフルオロ $-1,1$, 2,2 テトラヒドロオクチルトリクロロシラン $\left(\mathrm{C}_{8} \mathrm{H}_{4} \mathrm{Cl}_{3} \mathrm{~F}_{13} \mathrm{Si}\right)$ の 3 種類の有機ケイ素化合物を用いてコー ティングしたシリコン基板表面の撥水特性と而環境試験結 果について述べる。そして, $\mathrm{C}_{8} \mathrm{H}_{4} \mathrm{Cl}_{3} \mathrm{~F}_{13} \mathrm{Si}$ コーティングし た各種材料表面の撥水特性について述べる。最後に, $\mathrm{C}_{8} \mathrm{H}_{4} \mathrm{Cl}_{3} \mathrm{~F}_{13} \mathrm{Si}$ コーティング層のパターニングを目的とした 紫外線照射による分解特性について述べる。

\section{2. コーティング方法と評価方法}

図 1 にシリル化コーティング方法の流れを示す。コーテ イング処理は, 内製したマイクロマシニング装置(7)を用いて 行った。被コーティング試料は $\mathrm{p}$ 型，(100)面方位，比抵抗 10〜20 $\Omega \cdot \mathrm{cm}$ のシリコン基板を用いた。以下にコーティン グ処理の流れについて説明する。

（a）酸化膜系の犠牲層エッチングを想定し，被コーティン グ試料のシリコン基板を希 $\mathrm{HF}$ 処理 $\left(\mathrm{HF}: \mathrm{H}_{2} \mathrm{O}=1: 50\right.$, $23^{\circ} \mathrm{C}, 30$ 秒)し, シリコン基板表面の自然酸化膜を除去 し, 処理チャンバー内に設置する。

（b）処理チャンバー内の圧力が $5 \times 10^{-4}$ Torr に到達するま で真空引きする。

(c) $\mathrm{H}_{2} \mathrm{O}$ ガスを処理チャンバーに供給し, ガス圧が 1.0Torr に到達後, 1 分間保持する。

(d) $\mathrm{H}_{2} \mathrm{O}$ ガスを 5 分間排気する。

(e) 有機ケイ素化合物のガスを処理チャンバーに供給し, ガス圧が 0.1Torr に到達後，10 分間保持する。 (f) 有機ケイ素化合物のガスを 5 分間排気する。繰り返し 処理を行う場合は, (c)に戻る。

(a) Samples are put on the sample holder

$\boldsymbol{\gamma}$

(b) Evacuation (lower than $5 \times 10^{-4}$ Torr)

$\rightarrow \gamma$

(c) Feed and Hold of $\mathrm{H}_{2} \mathrm{O}$ Gas

$\checkmark$

(d) Exhaust of $\mathrm{H}_{2} \mathrm{O}$ Gas (5 min)

Iteration

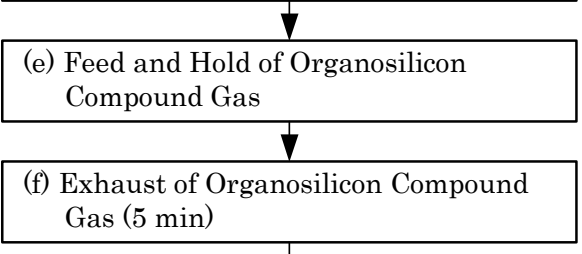

図 1 シリル化コーティング処理の流れ

Fig. 1. Procedure for silanization coating.

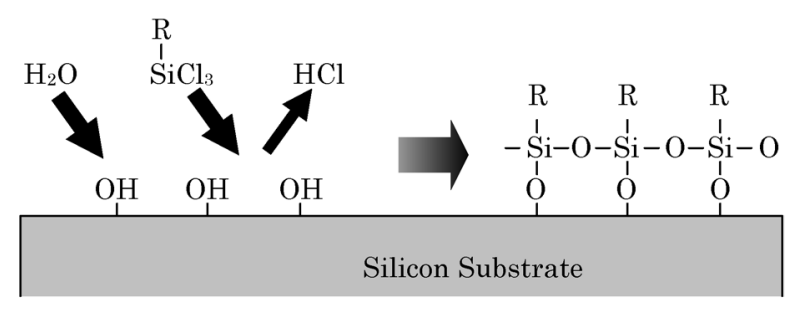

$\mathrm{R}: \mathrm{C}_{10} \mathrm{H}_{21}, \mathrm{C}_{6} \mathrm{H}_{4} \mathrm{~F}_{9}, \mathrm{C}_{8} \mathrm{H}_{4} \mathrm{~F}_{13}$

図 2 シリル化コーティング処理の反応概念図

Fig. 2. A shematic of the silanization reaction.

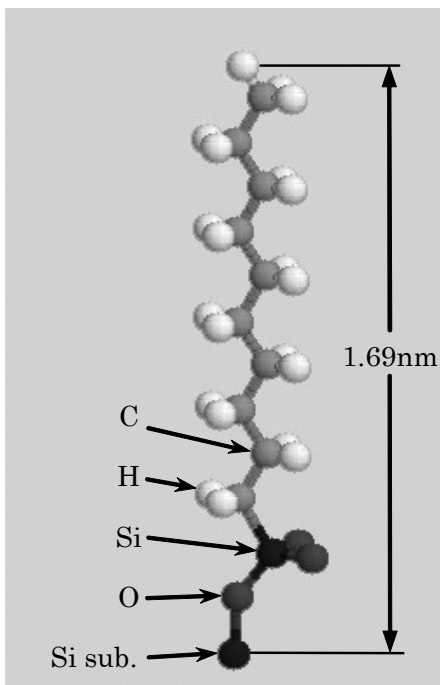

(a) $\mathrm{C}_{10} \mathrm{H}_{21} \mathrm{Cl}_{3} \mathrm{Si}$

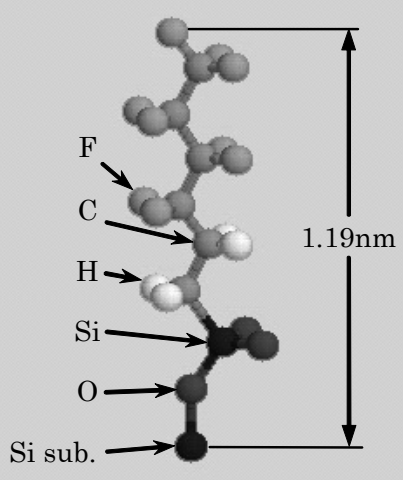

(b) $\mathrm{C}_{6} \mathrm{H}_{4} \mathrm{C}_{13} \mathrm{~F}_{9} \mathrm{Si}$

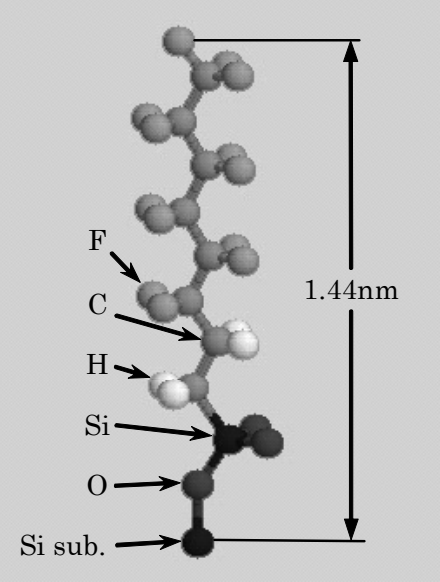

(c) $\mathrm{C}_{8} \mathrm{H}_{4} \mathrm{Cl}_{3} \mathrm{~F}_{13} \mathrm{Si}$

図 3 各種シリル化コーティング層の分子構造

Fig. 3. The molecular organization of three types of the silanization coating layers. 


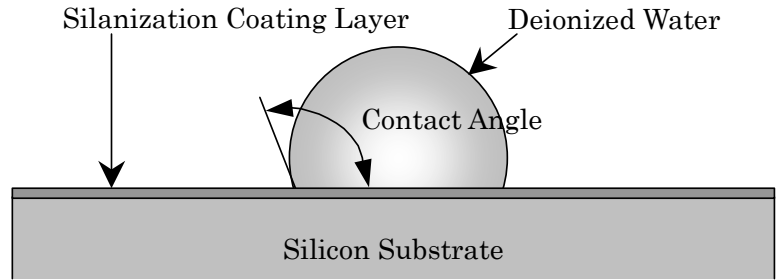

図 4 撥水特性の評価方法

Fig. 4. A shematic of a water droplet on the silicon surface.

有機ケイ素化合物のガスと $\mathrm{H}_{2} \mathrm{O}$ ガスによるコーティング 反応の概念図を図 2 に示す。 $\mathrm{H}_{2} \mathrm{O}$ ガスの供給によりシリコ ン基板表面に水酸基 $(\mathrm{OH})$ が形成される。次に，有機ケイ素 化合物のガスを供給し, $\mathrm{OH}$ と反応することにより, シリコ ン基板表面に対して垂直方向に規則正しく並んだ長鎖の単 分子膜のシリル化コーティング層が形成される。この反応 の際には極微量の塩酸 $(\mathrm{HCl})$ が発生する。

図 3 に各種有機ケイ素化合物を用いて形成されるシリル 化コーティング層の分子構造を示す。 $\mathrm{C}_{10} \mathrm{H}_{21} \mathrm{Cl}_{3} \mathrm{Si}$ コーティ ング層の最表面は $\mathrm{CH}_{3}$ 基, $\mathrm{C}_{6} \mathrm{H}_{4} \mathrm{Cl}_{3} \mathrm{~F}_{9} \mathrm{Si}$ と $\mathrm{C}_{8} \mathrm{H}_{4} \mathrm{Cl}_{3} \mathrm{~F}_{13} \mathrm{Si}$ のコーティング層の最表面は $\mathrm{CF}_{3}$ 基である。

撥水特性は，図 4 に示すようにコーティングしたシリコ ン表面に滴下した水の接触角により評価した。接触角が $90^{\circ}$ を超えると水に濡れたとしても構造体のスティッキン グは防止できる。接触角の測定には, 接触角精密測定装置(協 和界面科学, CA-A 型)を用いた。

\section{3. 実験結果と考察}

〈3.1〉撥水特性の処理回数依存性 図 5 に水に対す る接触角の処理回数依存性を示す。処理回数 0 は希 $\mathrm{HF}$ 処 理直後のシリコン基板表面の接触角 $\left(73^{\circ}\right)$ である。

$\mathrm{C}_{6} \mathrm{H}_{4} \mathrm{Cl}_{3} \mathrm{~F}_{9} \mathrm{Si}$ と $\mathrm{C}_{8} \mathrm{H}_{4} \mathrm{Cl}_{3} \mathrm{~F}_{13} \mathrm{Si}$ のガスを用いたコーティング 層は, 処理回数 1 回で接触角は $90^{\circ}$ を越え, 処理回数の増 加に伴い接触角は高くなり, 4 回以上で接触角は安定するこ とがわかった。このように処理回数の増加に伴い接触角が 向上するのは，以下の機構であると考えている。コーティ ング前の希 $\mathrm{HF}$ 処理により, シリコン基板表面は水素によ りターミネーションされている。コーティング処理におけ る $\mathrm{H}_{2} \mathrm{O}$ ガスの供給により水素と水酸基が置き換わった領域 は，有機ケイ素化合物のガスと縮合反応を起こし，シリル 化コーティング層が形成される。しかし，本条件における 1 回の処理では, 水素と水酸基の置き換わりが不十分であり, 複数回の処理を繰り返し行うことにより斑のないシリル化 コーティング層が得られる。

$\mathrm{C}_{10} \mathrm{H}_{21} \mathrm{Cl}_{3} \mathrm{Si}$ のガスを用いたコーティング層は, 処理回数 2 回以上で接触角は $90^{\circ}$ を越えるが，処理回数を増加させ ても接触角の向上は見られなかった。処理回数 10 回におけ る $\mathrm{C}_{10} \mathrm{H}_{21} \mathrm{Cl}_{3} \mathrm{Si}, \mathrm{C}_{6} \mathrm{H}_{4} \mathrm{Cl}_{3} \mathrm{~F}_{9} \mathrm{Si}, \mathrm{C}_{8} \mathrm{H}_{4} \mathrm{Cl}_{3} \mathrm{~F}_{13} \mathrm{Si}$ の接触角は, それぞれ $93^{\circ} ， 98^{\circ} ， 103^{\circ}$ であった。

表1に各種表面の表面エネルギーをまとめた ${ }^{(10)}$ 。参考デー

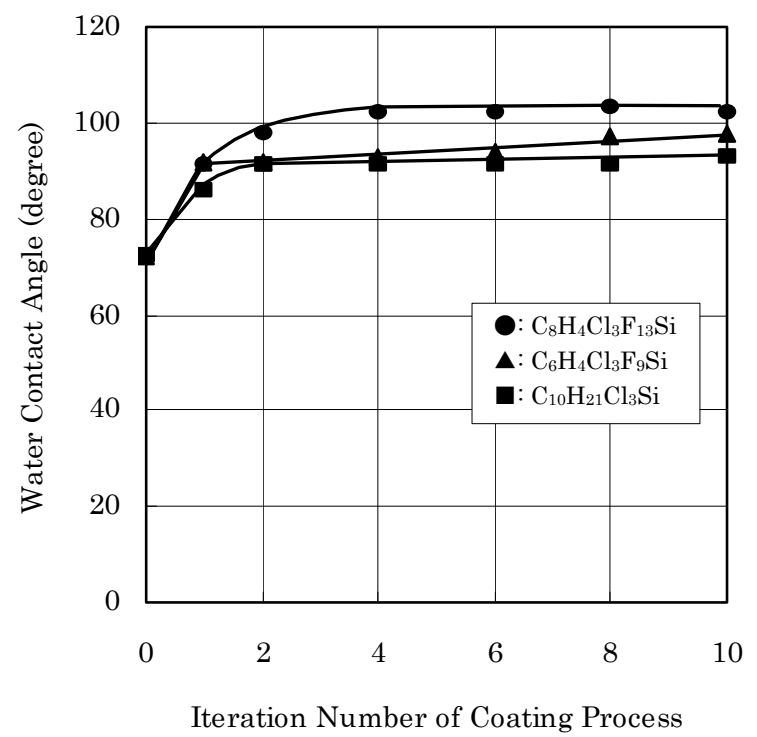

図 5 水の接触角と処理回数の関係

Fig. 5. Water contact angles of silicon substrates treated by the silanization coating.

表 1 各種表面の表面エネルギー

Table 1. Surface energy of various surface condition.

\begin{tabular}{|c|c|}
\hline Surface Condition & Surface Tension $(\mathrm{mN} / \mathrm{m})$ \\
\hline $\mathrm{CF}_{3}$ groups & 6 \\
\hline $\mathrm{CH}_{3}$ groups & 24 \\
\hline Teflon & 18 \\
\hline Paraffin & 30 \\
\hline $\mathrm{SiO}_{2}$ groups & 600 \\
\hline
\end{tabular}

タとしてテフロン, パラフィン, $\mathrm{SiO}_{2}$ 基の表面エネルギー も併記した。 $\mathrm{CF}_{3}$ 基を最表面に持つ $\mathrm{C}_{6} \mathrm{H}_{4} \mathrm{Cl}_{3} \mathrm{~F} 9 \mathrm{Si}$ と $\mathrm{C}_{8} \mathrm{H}_{4} \mathrm{Cl}_{3} \mathrm{~F}_{13} \mathrm{Si}$ のコーティング層は， $\mathrm{CH}_{3}$ 基を最表面に持つ $\mathrm{C}_{10} \mathrm{H}_{21} \mathrm{Cl}_{3} \mathrm{Si}$ に比べ, 表面エネルギーが低いので撥水特性に 優れる。

〈3・2〉耐環境試験シリル化コーティング層の耐熱 性, 而湿性, 各種溶液に対する而性について評価した。表 2 に試験結果をまとめた。各試験後の水に対する接触角が $90^{\circ}$ 以上で耐性を有するものと判定した。本処理法では, $\mathrm{C}_{6} \mathrm{H}_{4} \mathrm{Cl}_{3} \mathrm{~F}_{9} \mathrm{Si}$ と $\mathrm{C}_{8} \mathrm{H}_{4} \mathrm{Cl}_{3} \mathrm{~F}_{13} \mathrm{Si}$ のコーティング層が $\mathrm{C}_{10} \mathrm{H}_{21} \mathrm{Cl}_{3} \mathrm{Si}$ に比べ，耐環境特性に優れることがわかった。 $\mathrm{C}_{10} \mathrm{H}_{21} \mathrm{Cl}_{3} \mathrm{Si}$ のコーティング層は $50^{\circ} \mathrm{C}$ の熱処理により接触 角が $90^{\circ}$ と低下寸ることから，本処理法では完全にシロキ サン結合(Si-O-Si 結合)していないため, 耐久性が低かった と考えられる。

以下，撥水特性，耐環境特性に優れる結果が得られた $\mathrm{C}_{8} \mathrm{H}_{4} \mathrm{Cl}_{3} \mathrm{~F}_{13} \mathrm{Si}$ を用いたコーティング層の特性について述べ る。

〈3・3 各種材料表面の撥水特性 $\quad \mathrm{C}_{8} \mathrm{H}_{4} \mathrm{Cl}_{3} \mathrm{~F}_{13} \mathrm{Si}$ コー ティング処理が標準の半導体材料に使用できるか否かを明 
表 2 各種シリル化コーティング層の試験結果

Table 2. Results of durability test of the silanization coating layers.

\begin{tabular}{|c|c|c|c|c|c|}
\hline \multicolumn{3}{|c|}{ Test Items } & \multicolumn{3}{|c|}{ Organosilicon Compounds } \\
\hline & Items & Condition & $\mathrm{C}_{10} \mathrm{H}_{21} \mathrm{Cl}_{3} \mathrm{Si}$ & $\mathrm{C}_{6} \mathrm{H}_{4} \mathrm{Cl}_{3} \mathrm{~F}_{9} \mathrm{Si}$ & $\mathrm{C}_{8} \mathrm{H}_{4} \mathrm{Cl}_{3} \mathrm{~F}_{13} \mathrm{Si}$ \\
\hline \multicolumn{2}{|c|}{ Heat Resistance } & $100 \sim 500{ }^{\circ} \mathrm{C}, 30 \mathrm{~min}$ & $50{ }^{\circ} \mathrm{C}(90)$ & $300{ }^{\circ} \mathrm{C}(92)$ & $300{ }^{\circ} \mathrm{C}(96)$ \\
\hline \multicolumn{2}{|c|}{ Low-temperature } & $-30{ }^{\circ} \mathrm{C}, 30 \mathrm{~min}$ & $\mathrm{D}(92)$ & $\mathrm{D}(96)$ & $\mathrm{D}(99)$ \\
\hline \multicolumn{2}{|c|}{ Moisture Resistance } & $75{ }^{\circ} \mathrm{C}, 40 \sim 95 \% \mathrm{RH}$ & N. D. (60) & $\mathrm{D}(93)$ & $\mathrm{D}(98)$ \\
\hline \multicolumn{2}{|c|}{ Deionized Water } & R. T., $30 \sim 120 \mathrm{~min}$ & N. D. (89) & $\mathrm{D}(94)$ & $\mathrm{D}(97)$ \\
\hline \multirow{3}{*}{$\begin{array}{l}\text { Organic } \\
\text { Solvent }\end{array}$} & 2-Butanon & R. T., $30 \mathrm{~min}$ & N. D. (88) & $\mathrm{D}(94)$ & $\mathrm{D}(94)$ \\
\hline & Acetone & R. T., $30 \mathrm{~min}$ & $\mathrm{D}(92)$ & $\mathrm{D}(96)$ & $\mathrm{D}(96)$ \\
\hline & Methanol & R. T., $30 \mathrm{~min}$ & N. D. (88) & $\mathrm{D}(96)$ & $\mathrm{D}(94)$ \\
\hline \multirow{2}{*}{$\begin{array}{l}\text { Hydrofluoric } \\
\text { Acid }\end{array}$} & Diluted HF & R. T., $30 \mathrm{~min}$ & N. D. (86) & N. D. (78) & N.D. (76) \\
\hline & Buffered HF & R. T., $30 \mathrm{~min}$ & $\mathrm{D}(92)$ & N. D. (80) & $\mathrm{D}(96)$ \\
\hline
\end{tabular}

The number in the parenthesis indicates the water contact angle after the tests. R. T. :room temperature, D: durable, N. D. :no durable

表 3 シリル化コーティング処理前後の撥水特性

Table 3. Water-repellency characteristics of the before and after the $\mathrm{C}_{8} \mathrm{H}_{4} \mathrm{Cl}_{3} \mathrm{~F}_{13} \mathrm{Si}$ coating.

\begin{tabular}{|c|c|c|c|c|}
\hline \multicolumn{2}{|c|}{ Evaluation Materials } & \multicolumn{2}{|c|}{$\begin{array}{c}\text { Water Contact Angle } \\
\text { (degree) }\end{array}$} & \multirow{2}{*}{ Judge* } \\
\hline $\begin{array}{c}\text { Deposition } \\
\text { Method }\end{array}$ & Materials & Before & after & \\
\hline $\begin{array}{c}\text { Thermal } \\
\text { Oxide }\end{array}$ & $\mathrm{SiO}_{2}$ & $<5$ & 100 & $\bigcirc$ \\
\hline LPCVD & $\mathrm{Si}_{3} \mathrm{~N}_{4}$ & 30 & 102 & $\bigcirc$ \\
\hline \multirow{4}{*}{ Sputtering } & $\mathrm{Al}-\mathrm{Si}-\mathrm{Cu}$ & 69 & 106 & $\bigcirc$ \\
\cline { 2 - 5 } & $\mathrm{Al}-\mathrm{Cu}$ & 70 & 103 & $\bigcirc$ \\
\cline { 2 - 5 } & $\mathrm{Ti}$ & 63 & 103 & $\bigcirc$ \\
\cline { 2 - 5 } & $\mathrm{W}$ & 33 & 123 & $\bigcirc$ \\
\hline \multirow{3}{*}{$\begin{array}{c}\text { Vacuum } \\
\text { Evaporation }\end{array}$} & $\mathrm{Al}$ & 70 & 110 & $\bigcirc$ \\
\cline { 2 - 5 } & $\mathrm{Ti}$ & 71 & 114 & $\bigcirc$ \\
\cline { 2 - 5 } & $\mathrm{Ni}$ & 68 & 79 & $\times$ \\
\hline
\end{tabular}

*) $\bigcirc$ : greater than 90 degrees, $\times$ : less than 90 degrees

表 4 各種結合の結合エネルギー

Table 4. Bond energy of various chemical bond.

\begin{tabular}{|c|c|}
\hline Chemical Bond & Bond Energy $(\mathrm{kJ} / \mathrm{mol})$ \\
\hline C-F & 485 \\
\hline C-H & 414 \\
\hline C-C & 347 \\
\hline Si-C & 360 \\
\hline
\end{tabular}

らかにするため, 各種材料表面へのコーティング実験を行 つた。表 3 に各種材料表面の $\mathrm{C}_{8} \mathrm{H}_{4} \mathrm{Cl}_{3} \mathrm{~F}_{13} \mathrm{Si}$ コーティング処 理前後の撥水特性を示す。コーティング処理の繰り返し回 数は，5回一定である。ニッケル以外の材料は， $100^{\circ}$ 以上 の接触角が得られることが確認された。ニッケルはコーテ ィング処理中に生成される塩化物の影響によりコーティン
グ層の形成が妨害されると推定される。同一の $\mathrm{C}_{8} \mathrm{H}_{4} \mathrm{Cl}_{3} \mathrm{~F}_{13} \mathrm{Si}$ コーティング層を形成したにも係わらず，接 触角に違いが見られた。これは, 材料によって $\mathrm{C}_{8} \mathrm{H}_{4} \mathrm{Cl}_{3} \mathrm{~F}_{13} \mathrm{Si}$ 分子の形成密度や基板表面に対する傾きが異なると考えら れる。

〈3·4〉紫外線照射によるシリル化コーティング層の分 解特性 シリル化コーティングはウエハプロセスの終盤 に行われるため, ボンディングパッドなどの不要な箇所も コーティングしてしまう。そこで, $\mathrm{C}_{8} \mathrm{H}_{4} \mathrm{Cl}_{3} \mathrm{~F}_{13} \mathrm{Si}$ コーティ ング層のパターニングについて検討した。シリル化コーテ イング層を分解する方法の一つとして, 大気中における紫 外線(UV)照射がある(11) (14)。UV 照射により $\mathrm{C}_{8} \mathrm{H}_{4} \mathrm{Cl}_{3} \mathrm{~F}_{13} \mathrm{Si}$ コーティング層が分解除去できれば, 不要な箇所のみに UV 照射できるマスク部品を用いて $\mathrm{C}_{8} \mathrm{H}_{4} \mathrm{Cl}_{3} \mathrm{~F}_{13} \mathrm{Si}$ コーティング 層のパターニングが可能となる。表 4 に $\mathrm{C}_{8} \mathrm{H}_{4} \mathrm{Cl}_{3} \mathrm{~F}_{13} \mathrm{Si}$ コー ティング層を構成する各種結合の代表的な結合エネルギー をまとめた(15)(16)。これらの中で結合エネルギーの低い C-C 結合, $\mathrm{Si}-\mathrm{C}$ 結合を切断するためには, それぞれ $345 \mathrm{~nm}$, $322 \mathrm{~nm}$ 以下の波長の UV を照射する必要がある(17)。そこで, $185 \mathrm{~nm}$ と $254 \mathrm{~nm}$ の波長の UV を照射する低圧水銀ランプ による $\mathrm{C}_{8} \mathrm{H}_{4} \mathrm{Cl}_{3} \mathrm{~F}_{13} \mathrm{Si}$ コーティング層の分解を試みた。

分解実験には，シリコン基板表面に $\mathrm{C}_{8} \mathrm{H}_{4} \mathrm{Cl}_{3} \mathrm{~F}_{13} \mathrm{Si}$ コーテ イングを 5 回繰り返し処理した試料を用いた。また, UV は 大気中での減衰が大きいので, 光源と試料との距離は $10 \mathrm{~mm}$ と近接させた。この時の試料表面での光強度は, $4 \mathrm{~mW} / \mathrm{cm}^{2}$ である。図 6 に UV 照射時間と水に対する接触角 の関係を示す。UV 照射時間の増加に伴い水の接触角は低下 し, 3 分間の UV 照射により, 接触角は $5^{\circ}$ 以下の親水性と なることがわかった。UV 照射により $\mathrm{C}_{8} \mathrm{H}_{4} \mathrm{Cl}_{3} \mathrm{~F}_{13} \mathrm{Si}$ コーテ イング層が分解除去されていることを明らかにするため, $\mathrm{X}$ 線光電子分光分析(XPS)を行った。表 5 にUV 照射前後のシ リコン基板表面の XPS 結果を示す。UV 照射時間の増加に 伴いコーティング層の構成元素のフッ素が減少することが わかった。これらの結果より, $\mathrm{C}_{8} \mathrm{H}_{4} \mathrm{Cl}_{3} \mathrm{~F}_{13} \mathrm{Si}$ コーティング 


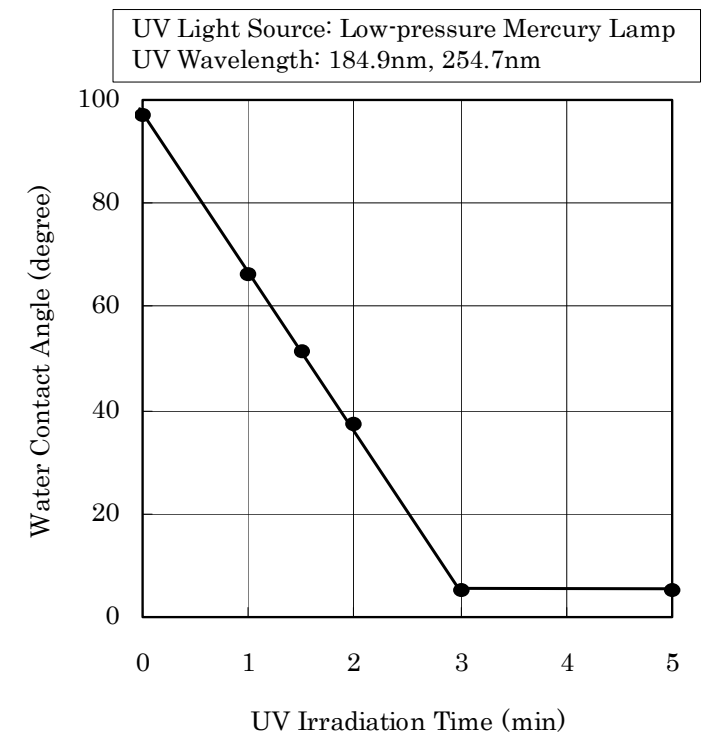

図 6 水の接触角と UV 照射時閒の関係

Fig. 6. Water contact angle vs. UV irradiation time.

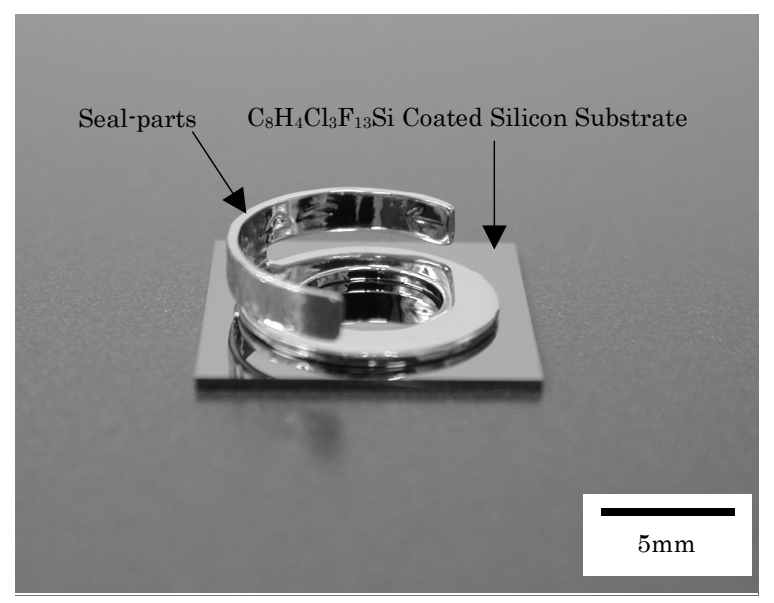

(a) UV 照射時のセッティング状況

(a) Setting condition during UV irradiation

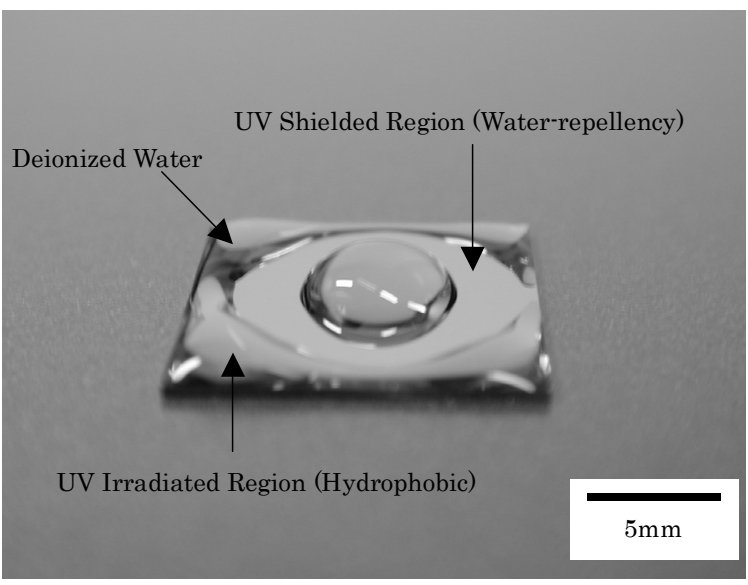

(b) UV 照射後、純水を滴下

(b) Water is dropped on the silicon surface after UV irradiation

図 7 シリル化コーティング層のパターニング

Fig. 7. Test result of patterning of the $\mathrm{C}_{8} \mathrm{H}_{4} \mathrm{C}_{13} \mathrm{~F}_{13} \mathrm{Si}$ coating layer.

\section{表 5 UV 照射前後の元素組成比}

Table 5. Elementary composition ratio of before and after the UV irradiation.

\begin{tabular}{|c|c|c|c|c|}
\hline \multirow{2}{*}{$\begin{array}{c}\text { UV Irradiation } \\
\text { Time (min) }\end{array}$} & \multicolumn{4}{|c|}{ Elementary (at\%) } \\
\cline { 2 - 5 } & $\mathrm{C}$ & $\mathrm{O}$ & $\mathrm{F}$ & $\mathrm{Si}$ \\
\hline No Irradiation & 18 & 25 & 14.2 & 43 \\
\hline 1.5 & 16 & 36 & 6.8 & 42 \\
\hline 3.0 & 14 & 43 & 0.9 & 42 \\
\hline
\end{tabular}

層はUV 照射により分解除去できることが確認された。

図 7 に $\mathrm{C}_{8} \mathrm{H}_{4} \mathrm{Cl}_{3} \mathrm{~F}_{13} \mathrm{Si}$ コーティング層のパターニング実験 結果を示す。シリコン基板表面に $\mathrm{C}_{8} \mathrm{H}_{4} \mathrm{Cl}_{3} \mathrm{~F}_{13} \mathrm{Si}$ コーティン グした試料を準備し, 試料の上に継手部品のシール材を置 き(図 7-a)，3 分間の UV 照射を行った。UV 照射後, シー ル材を取り外し, 水を滴下した(図 7-b)。シール材により遮 光された部分は撥水性を維持し, UV 照射された部分は親水 性に変化している。この結果より, 本処理法により形成し た $\mathrm{C}_{8} \mathrm{H}_{4} \mathrm{Cl}_{3} \mathrm{~F}_{13} \mathrm{Si}$ コーティング層は UV 照射によりパターニ ングできることが確認された。

\section{4. まとめ}

MEMS に用いる可動構造体が動作中においてシリコン基 板や別の構造体へのスティッキングを防止する方法とし て, 水蒸気と有機ケイ素化合物のガスを交互に供給して形 成した撥水性シリル化コーティング層の諸特性について評 価した。3 種類の有機ケイ素化合物 $\left(\mathrm{C}_{10} \mathrm{H}_{21} \mathrm{Cl}_{3} \mathrm{Si}\right.$, $\left.\mathrm{C}_{6} \mathrm{H}_{4} \mathrm{Cl}_{3} \mathrm{~F}_{9} \mathrm{Si}, \mathrm{C}_{8} \mathrm{H}_{4} \mathrm{Cl}_{3} \mathrm{~F}_{13} \mathrm{Si}\right)$ のガスを用いてコーティング したシリコン基板表面の撥水特性と耐環境特性を評価し, $\mathrm{C}_{8} \mathrm{H}_{4} \mathrm{Cl}_{3} \mathrm{~F}_{13} \mathrm{Si}$ コーティング層が最も撥水特性, 而環境特性 に優れることがわかった。そして, $\mathrm{C}_{8} \mathrm{H}_{4} \mathrm{Cl}_{3} \mathrm{~F}_{13} \mathrm{Si}$ コーティ ング層は, ニッケル以外の標準の半導体材料表面において, 水に対する接触角が $100^{\circ}$ を超える良好な撥水特性を有す ることが確認できた。さらに，低圧水銀ランプを用いた柴 外線照射 $\left(185 \mathrm{~nm}\right.$ と $254 \mathrm{~nm}$ の波長)により $\mathrm{C}_{8} \mathrm{H}_{4} \mathrm{Cl}_{3} \mathrm{~F}_{13} \mathrm{Si}$ コ ーティング層は分解することを明らかにした。これにより, 不要な箇所のコーティング層をドライフェーズでの除去が 可能となった。本処理法による撥水性シリル化コーティン グ技術は，マイクロセンサや MEMS のさらなる高性能化の ための有用な技術であるといえよう。

(平成 17 年 5 月 26 日受付, 平成 17 年 9 月 30 日再受付)

\section{文献}

(1) J. B. Brzoska, L. Benazouz, and F. Rondelez : "Silanization of solid substrates - A step toward reproducibility", Langmuir, Vol.10, pp.4367-4373 (1994)

(2) K. Deng, R. J. Collins, M. Mehregany, and C. N. Sukenik : "Performance Impact of Monolayer Coating of Polysilicon Micromotors", J. Electrochem. Soc., Vol.142, pp.1278-1285 (1995) 
(3) U. Srinivasan, M. R. Houston, R. T. Howe, and R. Maboudian : "Alkyltrichlorosilane-Based Self-Assembled Monolayer Films for Stiction Reduction In Silicon Micromachines", J. Microelectromechanical Systems, Vol.7, No.2, pp.252-260 (1998)

(4) J. A. Henry, Y. Wang, and M. A. Hines : "Controlling Energy Dissipation and Stability of Micromechanical Silicon Resonators with Self-Assembled Monolayers", Appl. Phys. Lett., Vol.84, No.10, pp.1765-1767 (2004)

(5) G. Y. Jung, Z. Li, W. Wu, Y. Chen, D. L. Olynick, S. Y. Wang, W. M. Tong, and R. S. Williams : "Vapor-Phase Self-Assembled Monolayer for Improved Mold Release in Nanoimprint Lithography", Langmuir, Vol.21, No.4, pp.1158-1161 (2005)

(6) A. Hozumi, K. Ushiyama, H. Sugimura, and O. Takai : "Fluoroalkylsilane Monolayers Formed by Chemical Vapor Surface Modification on Hydroxylated Oxide Surfaces", Langmuir, Vol.15, No.22, pp.7600-7604 (1999)

(7) K. Shimaoka, J. Sakata, and Y. Mitsushima : "A Full-dry Processing Technique from Sacrificial Layer Etching to Water-repellent Coating", Proc. of the 19th Sensor Symposium, pp.309-313 (2002)

(8) J. Sakata, T. Tsuchiya, A. Inoue, S. Tokumitsu, and H. Funabashi : "Anti-Stiction Silanization Coating to Silicon Micro-Structures by Vapor Phase Deposition Process", Proc. of the 10th In t. Conf. On Solid-State Sensor and Actuators, Sendai, Japan, pp.26-29 (1999)

(9) K. Shimaoka, H. Hosokawa, H. Funabashi, and Y. Mitsushima : "A Water-Repellent Silanization Coating Technique for MEMS", Proc. of the 21th Sensor Symposium, pp.211-214 (2004)

（10） 渡辺信淳・渡辺 昌・玉井康勝 : 表面および界面，共立出版, p.125 (1973)

（11）照明学会：「光科学産業用光源の技術動向と将来展望」，光科学産業 用光源調査委員会報告書 (1991)

(12) Y. Masuda, T. Sugiyama, H. Lin, W. S. Seo, and K. Koumoto : "Selective Deposition and Micropatterning of Titanium Dioxide Thin Film on Self-Assembled Monolayers", Thin Solid Films, 382, pp.153-157 (2001)

(13) N. Saito, H. Haneda, T. Sekiguchi, N. Ohashi, I. Sakaguchi, and K. Koumoto : "Low-Temperature Fabrication of Light-Emitting Zinc Oxide Micropatterns using Self-Assembled Monolayers", Adv. Mater., 14, No.6, pp.418-421 (2002)

(14) Y. Gao, Y. Masuda, T. Yonezawa, and K. Koumoto : "Site-Selective Deposition and Micropatterning of $\mathrm{SrTiO}_{3}$ Thin Film on Self-Assembled Monolayers by the Liquid Phase Deposition Method", Chem. Mater., Vol.14, pp.5006-5014 (2002)

（15）湯川泰秀 - 向山光昭 : パイン有機化学 [ I ], 廣川書店, p.42 (1994)

(16) N. N. Greenwood and A. Earnshaw : "Chemistry of the Elements", p.389 (1984)

(17) M. Hosaka, M. Asada, and M. Ishimori : "Modification of Organic Pigments using UV Radiation under Oxygen Atomosphere", DIC Technical Review, No.5, pp.45-50 (1999)

島 岡 敬 一 (正員) 1960 年 8 月 8 日生。1984 年 3 月名

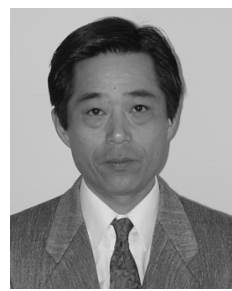
古屋工業大学機械工学科卒業。1979 年 4 月 (株) 豊田中央研究所入社。半導体ひずみゲージ，拡 散型圧力センサの研究に従事。1985 年以降シ リコンマイクロセンサ, マイクロマシニング技 術の研究を行う。精密工学会会員。

細 川 秀 記 (非会員) 1963 年 3 月 29 日生。1994 年 3 月

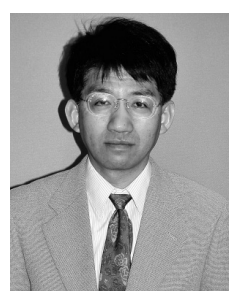
名古屋工業大学電気情報工学科卒業。1983 年 3 月(株) 豊田中央研究所入社。LSI プロセス, 半 導体デバイス，センサの研究に従事。応用物理 学会会員。

船 橋 博 文

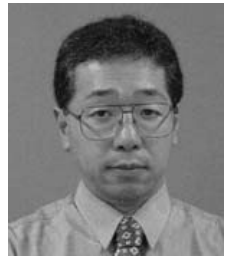

光 嶋 康 -

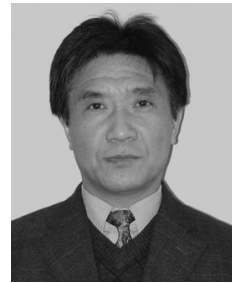

（非会員） 1959 年 8 月 7 日生。 1982 年 3 月名 古屋工業大学電子工学科卒業。1982 年 4 月(株) 豊田中央研究所入社。半導体圧力七ンサ, 加速 度センサ，ジャイロの研究に従事。応用物理学 会会員。
(非会員) 1953 年 2 月 25 日生。 1975 年 3 月 名古屋大学原子核工学学科卒業。1980 年 3 月 名古屋大学原子核工学専攻博士課程修了。 1991 年(株) 豊田中央研究所入社。半導体デバ イス, センサの研究に従事。工学博士。応用物 理学会会員。 